\title{
Bländas ömkliga ättlingar eller det inhiberade käringamötet hos Elin Wägner
}

\author{
Inger Littberger Caisou-Rousseau
}

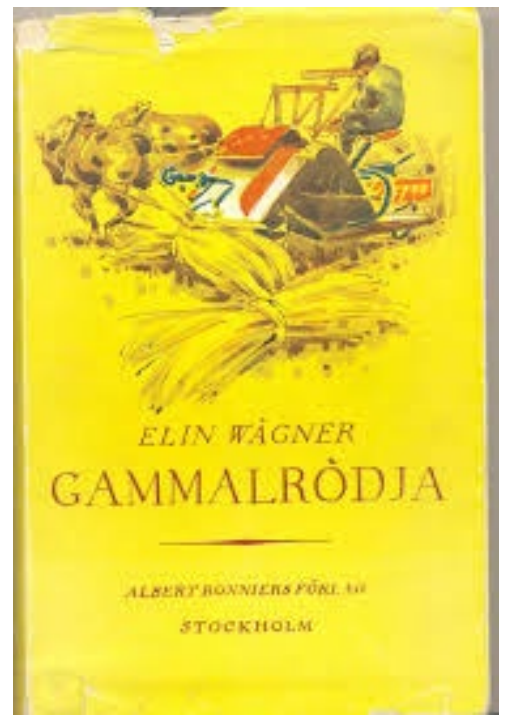

Sommaren 1930 påbörjade Elin Wägner (1882-1949) novellsamlingen Gammalrödja. Skildring från en bygd som ömsar skinn. Boken kom ut i november 1931 och fick ett gott mottagande av kritiken. Som framgår av titeln är temat för novellerna landsbygdens förändring. Att det inte är vilken bygd som helst utan den specifikt småländska som avses, måste man dock gå till novellerna själva för att upptäcka. De är så sammanhållna av miljö och ämne att de med Boel Hackmans ord "ger intryck av att vara en, om än mångstämmig och mångfacetterad, helhet" (Hackman 2005:149). Hon noterar att Wägners uppbrutna berättarstruktur har något experimentellt modernistiskt över sig och att den svarar mot den fragmentering och värdeupplösning som karakteriserar den moderna tid som skildras i boken. Men denna splittring till trots finns ett sammanhang som hur svåröverskådligt det än är, svarar mot det faktum att också människan hos Wägner är del av en helhet. Även sammanhållning och solidaritet hör den nya tiden till. I boken ställs modern vetenskap mot folktro. Ibland parodieras det gamla, men det händer också att dess goda sidor lyfts fram. En av texterna i samlingen bär titeln "Käringamötet". Den har fått förnyad aktualitet då den ingår i volymen Svenska noveller från Almqvist till Stoor (2018). När jag läste den slogs jag 
av hur sinnrikt den till synes enkla novellen är uppbyggd. I det följande förmedlar jag mina iakttagelser genom att följa texten tätt i spåren.

"Det är lyckligt för två äkta makar när deras värld är uppdelad i två riken. Det blir alltmera sällsynt, ty hemmet är snart inte något rike mer, och någon drottning behöver det inte" (Wägner 2018: 217). ${ }^{1}$ Så börjar berättelsen. Om någon annan än den för kvinnosaken engagerade Elin Wägner stått som författare till novellen, kunde man av titeln "Käringamötet" väntat sig något misogynt i bästa Albert Engström-stil. Nu slår de inledande raderna fast att det var bättre på den gamla goda tiden då kvinnan och mannen inom äktenskapet hade var sitt "rike" som de förfogade över, speciellt är det kvinnans degradering från sin drottningstatus som beklagas. Detta verkar vara i samklang med den särartsfeminism som bland andra Ellen Key förfäktade och som även Elin Wägner ställde sig bakom. Men ska vi ta den anonyma berättarrösten ad notam eller är novellens titel en indikation på att ironiska tongångar är att vänta?

I nästa mening förs vi abrupt från det abstrakta resonemangets nivå till det handfast konkreta: "Men Gammalrödja prästgård var på Springers tid ett dubbelrike, där var och en rådde över sitt" (s.217). Läsaren förstår att det här är en berättelse från den gamla tid som nyss med ett enda penseldrag skisserats som ett ideal. Dock hinner den goda ordningen knappt etableras förrän en ny oro inträder. "Det fanns bara en punkt där viljorna brötos. Mellan prosten och prostinnan rådde länge meningsskiljaktighet om söndagsfisket, och det var inte en sådan småsak som man kunde tro" (s. 217). Att på några korta meningar röra sig från ett högstämt anförande om forna tiders äktenskapliga riken till ett bråk om söndagsfisket är en handling nog halsbrytande för att vara värdig en raljerande berättare. Det visar sig att prosten Springer ser det som ett sabbatsbrott att vittja sina nät om söndagarna, och i detta får han också medhåll av sönerna, dock inte av teologiska skäl utan för att de vill sova i fred under dessa veckodagar. Prostinnan däremot hävdar med bestämdhet att det är mycket mera orätt att låta fisken hänga i maskorna till måndagsmorgonen. Och nu händer det komiska att detta triviala spörsmål får dimensioner av seriös livsåskådningsfråga: "Vad betydde den yttre formen för det reala innehållet, vad bokstaven för anden?" (s. 217) En teolog kunde inte ha formulerat det stiligare och teolog är ju just vad prosten är. Men än en gång förs vi snabbt ner på konkretionens fasta mark $\mathrm{i}$ och med prostinnans rättframma påpekande att det finns ett enkelt sätt att lösa konflikten så att bådas åsikter respekteras, nämligen att låta bli att lägga ut näten om lördagskvällarna.

Visserligen bestrider inte prosten att det är en riktig lösning, men om han lät sig nöja med detta skulle novellen obönhörligt ta slut innan den ens hunnit börja. Därför konstaterar berättaren att det finns vissa konsekvenser som man inte förmår ta här i världen ens om "det gäller frid med samvetet och hustrun på en gång, vilket annars är ett idealiskt tillstånd" (s. 217). Den djurvänliga

1 I fortsättningen ges sidhänvisningar till denna volym i den löpande texten. 
hustruns förnuftiga resonemang ratas således kategoriskt av hennes make och därmed är det idealiska tillståndet definitivt brutet och konflikten, liksom berättelsen, kan fortgå. Med andra ord får näten med sina fiskar i många år ligga orörda i sjön från lördag till måndag alltmedan striden pågår. Men så en lördagskväll när prosten ror ut är prostinnan plötsligt tyst. Han tror sig ha segrat, men känner sig fördenskull inte triumfatorisk utan tvärtom lite skamsen. Dock har han misstagit sig för tidigt på söndagsmorgonen väcker prostinnan pigan och tar med henne till sjön för att vittja. Nu gör dock de morgontrötta sönerna åter sina stämmor hörda och hävdar att det är djurplågeri (!) mot pigan att beröva henne morgonsömnen. Prostinnan inser det berättigade i detta till synes empatiska påpekande och gör i stället upp med Sara-till-Söderbergs att komma varje söndagsmorgon för att ro båten. Så mycket var det alltså bevänt med prostinnans medmänsklighet! Även om hon verkar mån om sin piga - vilket i och för sig kan betingas av egoism - drar hon sig inte för att utnyttja Sara.

Vem är då Sara? Det första som sägs om henne är att "Söderbergs behövde henne inte, de voro båda döda för femton år sedan" (s. 218). Nu är hon i stället gift med en dagsverkare "som troligen hade ett namn, men hon kallades ännu allmänt efter sitt forna döda herrskap och förvånade sig ej däröver, ty hon visste att hon var ett husgeråd" (s. 218). Ironin är här så skärande att ingen kan undgå dess budskap. Sara är en kvinna från underklassen och därmed inte mera värd än ett husgeråd - det är också som ett sådant hon säger ja tack till prostinnans anbud; hade hon något val undrar läsaren - och därför varje söndag tvingas kladda med fiskarnas blodiga inälvor "utan att någon kallade detta för djurplågeri" (s. 218). Hon gör det "med samma hopbitna tålamod som hon tvättade barntvätt, dränkte kattor åt känsliga personer, brände upp råttbon, nackade höns, plockade och tog ur dem” (s. 218). På ett suveränt sätt turneras här begreppet djurplågeri och laddas med betydelse. Här står klass mot klass - kvinna mot kvinna. För inte gör Sara detta frivilligt och inte är hon en okänslig människa utan empati för djur eller människor. Tvärtom förkunnar texten att ingen anar hur Saras "egna inkråm" (s. 218) - en kanske inte helt lyckad bild i sammanhanget - vänder sig vid de äckliga sysslorna. I stället tror man sig göra en god gärning då man förser henne med lite mat och en slant som tack för besväret. När hon kräks av äckel ömkar man henne för att hon ska ha "småfolk" (s. 218) igen.

Berättarrösten känner Saras innersta och förklarar att hon ägde "en levande och trotsigt resignerad själ" (s. 218). Trotsig och resignerad på samma gång. Hur hänger det ihop? Till skillnad från vad fallet är med det stereotypa prostparet bereds Sara plats i skildringen som människa med en nyanserad karaktär. Hennes syn på livet sägs avvika från den fastställda. Livet är för henne inte något absolut gott och inte bara en Guds gåva. Att hon ändå ständigt föder barn beror på att hon inte känner till någon utväg att få slippa. När barnmorskan som förlöst hennes åttonde barn yttrar att hon borde säga nej till karlen svarar Sara att han i detta fall går till andra och tröstar sig med 
att hon bara har sex år till femtio. Berättaren bekräftar att hon räknat rätt då den sista ungen föddes då hon var fyrtionio. Och så konstateras helt nyktert: "Men om den hoppades hon ömt och innerligt att han snart skulle tryta. Just det var vad hon tänkte en förtrollande morgon då hon åter begav sig ut att fiska med prostinnan, ty pojken var sjuk." (s. 219). När en mor "ömt och innerligt" önskar att hennes barn ska dö är något i grunden fel. Med andra ord: Om Sara har grymma förhoppningar så finns det en anledning till detta. Men hur är det med prostinnan som i novellens början verkade så klok och åtminstone omtänksam om fiskarna? I denna stund njuter hon av att efter de upprivande tankestriderna (!) kunna skönja stillheten som väntar efter fullbordad livsgärning. $\mathrm{Nu}$ är sonen Marcus redo att hålla sin första predikan och hon kan prisa den Gud som för henne är "Fullbordaren" (s. 219), men som för Sara bara ter sig underlig.

Så får prostinnan med läsaren för första gången blicka ner i vattnet och där urskilja alla de stackars fiskar som fastnat i snaran: "Resignerade och orörliga hängde de med ömma gälar i maskorna som om de varit en rad Saror-tillSöderbergs" (s. 219). Men om prostinnan inte har något till övers för Saras situation, ja inte ens reflekterar över den, så är hon desto mera öm mot fiskarna $\mathrm{i}$ deras utsatta belägenhet. Hon sölar avsiktligt när hon vittjar så att de ska kunna försvinna i djupet - prosten är ju inte med och kan kontrollera. Men även om många av de ångestfulla djuren lyckas undkomma så ligger massor på båtbottnen när fiskafänget är över. Det blir då Saras uppgift att bedöva dem genom att slå dem $\mathrm{i}$ huvudet med en sten, något hon avskyr att göra men hon kan inte "komma ur sitt ödes nät, förrän döden slog henne i huvudet med en sten" (s. 220). Saras likhet med de maktlösa fiskarna är härmed nästan övertydligt etablerad. Skillnaden är bara att prostinnan ömkar fiskarna, men inte känner något för Sara.

Under hemfärden kommer samtalet in på prostinnans unge son som inom kort alltså ska hålla sin första predikan - en ny prost i vardande. Denna predikan vill Sara inte missa hur det än går med Sigurd, hennes egen svårt sjuke son. Ligger hennes prioritet verkligen hos prostsonen eller utnyttjar hon honom för att förhoppningsvis kunna bli kvitt sin egen oönskade son? Kanske är dessa frågor egentligen en och densamma. När de kommit i land och är på väg med de tunga näten tar Sara plötsligt för första gången under sin bekantskap med prostinnan ett eget initiativ och sätter ner sin börda utan att först fråga om lov. Är det nu hennes trotsighet ska manifesteras undrar läsaren för att dock genast inse att så inte är fallet. Ett uppror är det ingalunda fråga om. Sara vill vända om då hon upptäckt att pastor Marcus är på väg i deras riktning och det måste med alla medel förhindras att han får ett "käringamöte" (s. 221) denna dag då så mycket står på spel för honom. Återigen är det alltså omsorgen om herrskapet som förestavar hennes handlingar. Prostinnan erkänner visserligen att det är omtänksamt men tillfogar genast att "sånt tror ingen längre på” (s. 221). Dock är hon inte så modernt fördomsfri som hon själv vill låta påskina då hon genast erinrar sig en baron som vrickat foten då 
han gav sig ut på jakt trots att han mött tre käringar. Att vidkännas sin vidskeplighet ser hon sig ändå för god för och med ett skratt för att markera att hon inte tar saken på allvar uppmanar hon Sara att springa. Men Sara är klokare än så och invänder att det ju är lika illa om prostinnan själv möter sin son. Och ännu en gång får novellen tillfälle att blotta prostinnans förmätenhet då det konstateras att hon trots att hon är femton år äldre än "sitt hjälpe" (s. 221) endast betraktat henne som käring, men aldrig sig själv. Prostinnan har därmed ohjälpligt avslöjat sig som både dryg och vidskeplig.

$\mathrm{Nu}$ slits prostinnan mellan lusten att demonstrativt gå och möta Marcus och därmed komma Saras räddhåga på skam, och att följa efter Sara "i ödmjukhet och självförglömmelse" (s. 222) - infernaliskt avslöjar detta ordval hennes inbilska förljugenhet till och med inför sig själv. Hon vet att redan hennes tvekan är ovärdig både henne själv och "hennes upplyste son" (s. 222), men hon hyser den likväl och får samtidigt lära sig att det inte varit så lätt för hennes man att låta bli att sätta ut näten om lördagskvällarna. Ska vi tolka detta som att också prosten är offer för "vidskepelse" i form av en stelbent auktoritär religiositet?

Samtidigt har Sara hunnit ner till bryggan och hennes rop om ett saknat lakan i vattnet - en fint från Saras sida - kommer väl till pass för prostinnan att rusa efter och därmed slippa gå ur vägen för sin son av vidskepliga skäl. Snart ligger de båda kvinnorna på bryggan och utgör en ömklig syn i kontrast till deras stolta drottninglika värendska anmödrar på den gamla goda tiden: "Ja, där lågo nu döttrarna av Bländas döttrar! Dessa som redo till bröllop, omgjordade med fälttecknet och beledsagade likt drottningar av musik, dessa som ärvde lika med broder och make på den tid då alla andra svenska kvinnor fingo nöja sig med hälften, dessa som haft sina egna stämmor, rådslag och lekar och sina egna gårdar och slott” (s. 222). Det tycks bara vara vidskepligheten som de bevarat från dessa praktkvinnors tid!

Vad har då hänt med pastor Marcus under tiden? Memorerande Bibelordet från Matteus 23:12 om att "var och en som upphöjer sig han skall vara förnedrad, och den sig förnedrar, han skall vara upphöjd”' (s. 221) är han på väg neråt sjön och när han så småningom får syn på de båda knäböjande kvinnorna på bryggan och inser att den ena är hans mor tror han att något hänt med näten. Men trots att han är "en upplyst ung man" (s. 222) och "intet av hedendomens mörker eller hedendomens respekt för trollkunniga gamla prästinnor och kloka kvinnor” (s. 222 f.) mera låder vid honom så finner han ändå för gott att osedd fortsätta sina tankar i stället för att gå ner och hjälpa kvinnorna med de förmenta näten. Käringamöte är trots allt käringamöte! Som om det var den kraftfulla Blända själv han riskerade att möta i stället för hennes bleka ättlingar. Så fortsätter han sin predikoförberedelse på ödmjukhetens tema, bara för att raskt komma underfund med att en sådan uppmaning till undergivenhet är onödig då hans väluppfostrade församling redan rättar sig efter denna förkunnelse sedan länge. Hela novellen är en dementi av detta påstående. Lika lite som kristendomens radikala budskap om 
den ringares upphöjelse har slagit rot lika bundna är unga som gamla innerst inne av det hedniska tänkesättet. Någon tingens nyordning i Gammalrödja är inte att förvänta - men inte heller en återgång till Bländas stolta tidevarv. Novellen slutar avsiktligt lamt med Saras konstaterande att pastorn har gått förbi. Därmed har alla nått sitt mål och ordningen är återställd.

\section{Referenser}

Hackman, Boel (2005), Boel Hackman om Elin Wägner. Stockholm: Albert Bonniers Förlag.

Wägner, Elin (2018). "Käringamötet", i Ingrid Elam och Jerker Virdborg (red.), Svenska noveller från Almqvist till Stoor. Stockholm: Albert Bonniers Förlag, s. 217-223. 